\title{
Religious Resilient School: A Mental Health School Study
}

\author{
Fitra Faturachman ${ }^{1}$, Rena Latifa ${ }^{2}$, Hesti Farida Al Bastari ${ }^{3}$, Risa Dwi Ratnasari ${ }^{4}$, Ricky Firmansyah ${ }^{5}$, \\ Anne Octavia ${ }^{6}$, Prasetyanto $\mathrm{GF}^{7}$, Adang Addha ${ }^{8}$, and Hena Rustiana ${ }^{9}$ \\ \{datuk.fitra@gmail.com ${ }^{1}$,rena.latifa@uinjkt.ac.id ${ }^{2}$ \} \\ Indonesian Mental Health Association, Promenade 20 Unit O, Jakarta, Indonesia ${ }^{1479}$ \\ Psychology Faculty, Islamic State University Syarif Hidayatullah Jakarta, Jakarta, Indonesia ${ }^{2}$ \\ Psychology Faculty, University of Indonesia, Depok, Indonesia ${ }^{3}$ \\ School of Global Strategic and Gender Studies, University of Indonesia, Jakarta, Indonesia ${ }^{5}$ \\ Psychology Faculty, YAI Persada Indonesia University, Jakarta, Indonesia ${ }^{6}$
}

\begin{abstract}
This study aims to find the correlation between religiosity, resilience, and mental health. We conducted a survey to 115 samples of public high school students at Depok, Indonesia (Mage=16.23, Male=31) to prove our hypothesis that high resilience and high religiosity positively correlate with positive mental health. We used Indonesian Version MHI-38 (Veit \& Ware, 1983) $(\alpha=0.658)$, Psychological Capital Resilience dimension (Luthans, 2002) $(\alpha=0.636)$, and adapted scale for religiosity from National Study of Youth and Religion (Pearce, 2016) $(\alpha=0.676)$. The result is that mental health well-being significantly correlated with resilience and religiosity $(\mathrm{p}<0.05)$, mental health personality distress negatively correlated with resilience $(\mathrm{p}<0.5)$ and negatively correlated with religiosity $(\mathrm{p}<0.5)$. Resilience and religiosity were highly correlated $(\mathrm{p}<0.001)$. We proposed a model for relationship between resilience, the five dimension of religiosity and mental health. This lead us to further discussion and research about the relationship between mental health, resilience, and religiosity at school.
\end{abstract}

Keywords: External Practice, Mental Health, Personal Practice, Psychological Distress, Psychological Well Being, Resilience, Religious Belief, Religious Exclusivity, Religious Salience, Religiosity.

\section{INTRODUCTION}

Indonesia Ministry of Health had released Basic Health Research in 2018, stated that mental health issues in Indonesia including smoking behavior, alcoholic abuse, psychosis, depression, and emotional disorder [1]. This research target was 1000 household in Indonesia from national survey. The results were that $33.8 \%$ of Indonesian population are still smoking, and that included $9.1 \%$ of $10-18$ years old population. Around $3.3 \%$ drink alcohol, and $0.8 \%$ of the population above 10 years old were alcohol abusive. Around $7 \%$ of the household had family member with psychosis, and $6.1 \%$ of the population above 15 years old, had depression. Among the population above 15 years old, $9.8 \%$ had emotional disorder. These findings had shown that mental health must be a crucial issues, especially in Indonesia.

The concept of Mental Health at School is not yet became a popular theme in the world of Indonesia education. Yet, we find that the research topics about mental health at school in 
2019, appeared with keyword such as deviant and problematic behaviors. Among the signs of mental health that can be observed from students were: 1) Learning difficulties, 2) Juvenile delinquencies, 3) Discipline, and 4) Mental Problems.

Generally, school are still focusing on academic achievement and physical health. In fact, mental health problems are also as important as physical health. Mental Health as defined by the World Health Organization [2], is a state of well-being in which every individual realizes his or her own potential, can cope with the normal stresses of life, can work productively, and able to make a contribution to her or his community.

According to the latest definition of mental health, it is a dynamic state of internal equilibrium which enables individuals to use their abilities in harmony with universal values of society. Basic cognitive and social skills; ability to recognize, express and modulate one's own emotions, as well as empathize with others; flexibility and ability to cope with adverse life events and function in social roles; and harmonious relationship between body and mind represent important components of mental health which contribute, to varying degrees, to the state of internal equilibrium [3].

Indonesia Mental Health Association used this latest definition of mental health, as proposed by Galderisi, et al. [3] because it presented the dynamics between internal equilibrium of individual with the community values, so that when we discuss the mental health, we also mentioned the self and social aspects.

When mental health was not well achieved, the students would frequently perform problematic behavior in their social environment. Problematic behavior such as aggressive behavior, for example, fighting, disturbing other students, or verbal aggressive behavior, including swearing, cursing others, mocking, speaking harshly, fighting teachers and spreading gossip about other people [4]; [5]. Deviant behavior includes premarital sex, skipping school, drug use, and suicidal thoughts [6].

Discussions about mental health at school were not only about problematic behavior and deviant behavior, but also the resiliency of the students and school employees, including the principal, teachers and administrations. By focusing to improve the resiliency, then the school would grow toward positive orientation and becoming a mentally healthy school.

During a three months resilience program that aims to promote mental health at school in Australia, children's optimism was significantly increased (Anthony \& McLean, 2015) [7]. The Bounce Back classroom resiliency program [8] was a whole school, universal program that promoting resilience and positive mental health by teaching social and emotional competencies and positive psychology skills. We would like to find out whether the same resiliency program could be conducted in Indonesia to promote mental health at school. In order to conduct the same program, we would like to know which kind of target that need to be promoted in resilience in order to have increase their mental health.

Previous study also discuss relationship between religiosity and mental health. A study about mental health school had compared social, emotional, and behavioral risks between parochial school and public school in Maryland, US [9]. It turned out that parochial school provide better social and academic experiences, but they might struggle with issues related to social, emotional, and behavioral health risk. The students of parochial school were more likely report being stressed and more likely to report being a cyberbully than students of public school.

The results of those mental health at school study made us want to confirm the relation between religiosity, resiliency, and mental health, especially in Indonesia context. We wanted to know the relationship between resiliency and positive mental health at Indonesia school, 
especially in public school. Whether the public school students resiliency lead to positive mental health. And in case of religiosity, we wanted to know does religiosity indeed lead to positive mental health, and if it does, which aspect of religiosity. Our hypothesis was that resiliency at public school lead to positive mental health, and higher religiosity lead to positive mental health.

\section{RESILIENCE, RELIGIOSITY, AND MENTAL HEALTH: BRIEF EXPLANATION OF THE IMPORTANT CONCEPTS}

In Psychology, resilience, well-being, and positive mental health have become familiar terms and essential constructs in trans-disciplinary integrative psychiatry, and psychology [10]. These recent years, religiosity has gained a central issue about its conceptualization, measurement, and relationships in research topic [11], However, the definition and relationship on the whole construct of religiosity is still in exploration to establish general agreement. Therefore, examining the use of these terms should always be accompanied by a brief explanation of respective expert's definition and theoretical framework [10].

\subsection{Mental Health}

Mental health is not only about the condition of mere lack of mental disorders, but also how persons can functioning effectively, can cope with the normal stresses of life, can work productively and fruitfully, and able to make a contribution to his or her surrounding environment [12]. The positive dimension of mental health is one of our concern issue. WHO states that: "Health is a state of complete physical, mental and social well-being and not merely the absence of disease or infirmity." [2]. Veit and Ware [13] pointed out that mental health has two dimensions: psychological distress and psychological well-being. Anger or irritability, anxiety and exhaustion are typical states of psychological distress, as well as the tendency to devalue and an inclination to isolate, stay away, not engaging in activities with others. Psychological well-being is often associated with happiness: a sense of balance and vitality accompanied by a feeling of self- worth are the most important characteristics [14].

In the 1950s and 1960s, researchers began to wonder how a number of seemingly extraordinary children managed to emerge from severely challenging circumstances relatively unscathed [15]. These findings lead us to what factors can lead to positive mental health. One of the factors is resiliency.

\subsection{Resilience}

Resilience is the condition of positive coping and adaptation of persons in their life that characterized with challenging reality and struggling life in the face of significant risk [16]. In this research, the resilience will be focus on work context that take out from dimension of psycap (HERO). Ogińska-Bulik, Juczyński [17] stated that resilience is an important feature of personality, conducive to good health and a "key to it" and may also be regarded as a "meta-source" of special regulatory power, influencing the activation of other resources needed in the process of coping with life events [18]. 
In work context, resilience is defined as the "positive psychological capacity to rebound, to 'bounce back' from adversity, uncertainty, conflict, failure, or even positive change, progress and increased responsibility [19].

Some research about resilience and mental health used Psycap to measure resilience [20]. We specifically measured the resilience and not the other dimensions, because we only focused on the relationship between resilience, religiosity, and mental health.

The resiliency in this research was adapted to work context of high school student. Since the student has also homework to do, they also doing their school work, house work and part time work. We seen that these works can lead to distress, or negative mental health, if cannot be managed.

\subsection{Religiosity}

The religiosity was also known with another term such as religiousness, orthodoxy, faith, belief piousness, devotion and holiness Holdcroft [21] The complexity is that current interest in the concept of religiosity correlated with several academic disciplines, each perspective field approaching religiosity from different points of view, and one is not refer to the other perspective [22]; [23]. Glock and Stark [24] are studying religious orientations, origins, and dimensions. in their focus discipline. Glock and Stark had investigate five dimensions of religiosity: experiential, ritualistic, ideological, intellectual, and consequential. Referring to the Glock and other religiosity construct researchers, Lisa Pearce had conducted validation to religiosity dimensions and found five dimensions that are ubiquitous across frameworks and have multiple valid empirical measures corresponding to these five dimensions (Pearce, Hayward, \& Pearlman, 2017). The five unique dimensions of religiosity that are important in the lives of adolescents are religious beliefs, religious exclusivity, external practice, personal practice, and religious salience [25]

Religious belief is what people call the "ideological" [26] or "doctrine" component [27] of religiosity. It defined as the acceptance of a standard set of religious beliefs, such as God, the afterlife, the supernatural, etc. It indicates a meaning system that involves a higher power and a sacred or supernatural realm.

Previous research found that religious belief has linked with physical and mental health [28]; [29]. For adolescents including school age students, this dimension is important to assess the development of their religious identity. The more mature and developed their cognitive skills, they can process their belief and religious belief becomes more authentic and representative of their own systems of meaning [30].

Religious exclusivity shares much in common with "doctrinal orthodoxy" [31] or "dogmatism", [32]. This dimension focus on orthodoxy or dogmatism, whether one holds particular religious beliefs to a more global belief in absolutes. It is the view that there are definite rights and wrongs - that rules for living are unambiguous, permanent, and ordained by God. This dimension also known as "religious fundamentalism" [33]. Youth who score high on religious exclusivity may be less tolerant of those they deem "wrong", in belief or action. They may also be less likely to engage in behaviors they consider "wrong," such as early sexual initiation or illicit drug or alcohol use.

Next dimension of religiosity is External Practice. It universally includes religious service attendance, group membership, and social activities. There is something unique about the practice of religion with other people and the resources that come from religious institutions and co-congregates [34]. For example, The study of adolescent sexual behavior that show the 
association with other religious variable with the time of sexual initiation and others could maintain its own statistically significant association to those behaviors [35]. In adolescence, they usually practice external forms of religiosity based on the request of their family, so this is one dimension of religiosity that may not always reflect adolescents' own religious commitments. As adolescents gain autonomy, it is likely that their level of religious service attendance is more reflective of their own interest in religion.

The fourth dimension is Personal Practice, the dimension that Lenski [31] referred to as "devotionalism," or an emphasis on means for a personal connection to the sacred. It involves religious behaviors usually done individually, thus requiring a level of personal dedication. This is the dimension that heavily reflects how adolescents practice their religion.

The final dimension is Religious Salience, that represents the place in one's hierarchy of identities that religion holds [36]. This dimension represents religion's relative position among other influential identities (e.g., friend, loving partner, popular student, or progressive) [37]. This dimension is likely to be most associated with whether one acts in line with religious values or schema [38]; [39]. It is unique to describe the potential level of influence that religion might have on other realms of life.

There were previous research studying the relationship between resilience and mental health, religiosity and mental health, or the correlation between the three variables.

Study about resilience had shown that it was a positive predictor for subjective well being [40]. Yet the discussion between resilience and mental health was about whether resiliency is the result of positive mental health, or resilient people makes better mental health. Study had proven that elements of psychological capital, including resiliency, are good predictor of mental health [41].

Some reviews showed that higher level of religiosity and spirituality were associated with better mental health [42];[43], even though some research showed the contradiction, that spirituality, but not religiosity, associated with better health and life satisfaction [44]; [45].

Indonesia is a country that have six formal religions as state religion. With majority number of Muslim citizens, there are also Christian, Catholics, Hindu, Buddha, and Kong $\mathrm{Hu}$ $\mathrm{Cu}$ (Confucianism) as the formal religion. Religion also taught at school as formal subjects, and beside public school, there were some Islamic School or Christian/Catholic School.

We suggest that if we conduct a study about resilience, religiosity, and mental health, the result will have some cross cultural differences with previous research in other countries. We hypothesized that in Indonesia, there is relationship between high level of religiosity and better mental health, and higher resilience will lead to higher score mental health. We want to know which one of the five dimension of religiosity that correlate with better mental health [25].

\section{METHODS}

\subsection{Participants}

One hundred and fifteen public high school students in suburban city Depok, Indonesia were recruited as participants for a national mental health survey (Mage=16.23, Male=31). There were 66 students $(57.39 \%)$ on the 11 th grade. Among the students, 103 mentioned Islam as their religion, 5 Christian, and 2 Catholics. The participants were given a ballpoint (on the same value as 0.5 USD) as a reward.

The survey were held after a final semester test. They were given a form of informed consent and debriefing form that mention the purpose of the research. 


\subsection{Materials}

There were three variables measured in the study, mental health was measured by Indonesian Version MHI-38 that was developed by Viet \& Ware [13], resiliency was measured with adapted resilience dimension from Psychological Capital Questionnaire [19], and religiosity measured with 21-item General Religiosity Scale, that developed from the Religiosity questionnaire [25].

We gave the questionnaire to 200 participants. We debriefed the participants by telling them the procedure of the study, and they chose whether they want to continue/exit from the survey. Finally, we asked the participants to fill a form with their initials, grade, sex, occupations, ethnicity, religion, family income, school, and city they lived in. The demographic variables were not analyzed in this study, but further study.

\subsubsection{Mental Health Questionnaire}

Indonesian Version MHI-38 is a questionnaire consists of 38 item that results on Global Mental Health Scale $(\alpha=0.658)$. It also results on two factors which are psychological distress (anxiety, depression, loss of behavioral/emotional control), such as "In the last month, how often do you feel anxious?" (1-6, 1=every time, $6=$ never $)(\alpha=0.594)$ and psychological wellbeing (general positive affect, emotional ties, and life satisfaction), such as "During the last month, does your daily life full of interesting things?" (1-6, 1=always, $6=$ never, reverse scored) $(\alpha=0.65)$.

Some items were reversed and scoring method used to get the global scale, psychological distress scale, and psychological well-being scale.

\subsubsection{Resilience Scale}

Resilience measured by 6 item resilience dimension of Psychological Capital Questionnaire, such as "I usually take stressful things at work in stride." $(\alpha=0.636)$ [19]. The questionnaire was altered to fit the target group participants which are the students. The Resilience dimension of Psycap Questionnaire aims to measure the resilience of people at work. We adapt the items to measure the resilience of the people at school, including the students and the school management. The resilience score were computed from the total score of the items, with one item was reversed.

\subsubsection{General Religiosity Scale}

We developed a 21-item General Religiosity Scale that was adapted from National Study of Youth and Religion which measures religious belief, religious exclusivity, external practice, personal practice, and religious salience [25] $\alpha=0.676)$. Some of the items included were "How often, if ever, do you pray by yourself alone?" $(1-7,1=$ never, $2=$ less than once a month, $3=$ once or twice a month, $4=$ about once a week, $5=$ several times a week, $6=$ about once a day, $7=$ many times a day) and "Do you believe in angels?" (1=maybe, or no; $2=y e s)$.

There were five score as a result from the scale, that represents each dimension of the religiosity scale. We also computed the total score of religiosity. Higher score means higher religiosity and lower score means lower religiosity. 


\subsection{Data Analysis}

We were conducting Principal Component Analysis to confirm the factors of the variables: mental health, resilience, and religiosity. Some items of MHI-38 were reversed score, and we checked the total score and the multidimensional score of the variables. PsyCap resilience score were unidimensional and we compute the total score of the variable. The General Religiosity Scale resulted on five score for five dimensions, and each score represented the total score of each dimension of religiosity. We also computed the total score of religiosity for correlation analysis.

Inter-item correlation and Alpha Cronbach for item reliability were measured. After conducting the Principal Component Analysis, we found that some items are not measuring any of the dimensions. This results will become the basis of our evaluation for next research.

One item in the General Religiosity Scale were not representing any of the factors, so the item will be dropped from further analysis.

We confirmed two factor of mental health, which is Personal Distress and Psychological Well Being, and five factor of religiosity: religious belief, religious exclusivity, external practice, personal practice, and religious salience. All the analysis conducted with JASP 10.0.

\subsection{Result and Discussion}

We got the description about the students mental health, which results on three score, mental health global scale (mean=156.236, $\mathrm{SD}=19.737)$, mental health personal distress (mean=65.645, SD=14.992), and mental health well-being (mean=54.102, $\mathrm{SD}=6.967$ ). Psycap Resilience total score (mean=23.609, $\mathrm{SD}=4.295$ ), and General Religiosity score (mean $=50.945, \mathrm{SD}=5.117$ ) which results on five dimensions: religious belief (mean=11.798, $\mathrm{SD}=0.612)$, religious exclusivity (mean $=7.296, \mathrm{SD}=0.805)$, external practice (mean=8.919, $\mathrm{SD}=2.516)$, personal practice (mean=14.482, $\mathrm{SD}=2.897)$, and religious salience (mean=8.393, $\mathrm{SD}=0.933$ ).

To prove our hypothesis that high level of religiosity correlate with better mental health, and higher resilience correlate with higher score mental health, we used matrix correlations between mental health well-being, personality distress, resilience, and religiosity.

Results of the correlation matrix had shown us that mental health well-being is very significantly correlated with resilience $(\mathrm{p}<0.001)$, and significantly correlated with total score of religiosity $(p<0.01)$. The religiosity factors that correlate with mental health well-being are religious salience $(\mathrm{p}<0.01)$ and personal practice $(\mathrm{p}<0.5)$. Mental health personality distress is negatively correlated with resilience $(\mathrm{p}<0.5)$ and negatively correlated with religiosity $(\mathrm{p}<0.5)$, significantly negatively correlated with personal practice $(\mathrm{p}<0.01)$. Resilience and religiosity are highly correlated $(\mathrm{p}<0.001)$.

From the results above, we found that positive mental health indeed correlate with high level of religiosity, specifically, the religious salience and personal practice. We can see that not all factors of religiosity correlate with positive mental health. We interpret that, from the results, the higher the religious salience, or the more internalized the identity of the religion to a student, the more positive his/her mental health is. Also the more often the student practice his/her religion practice individually, or privately, the more positive his/her mental health.

The relationship between religiosity and negative mental health, which is personal distress, also significant for just one factor of religiosity. That factor is, the personal practice. 
We can see that less often the student practice his/her religion practice individually, or privately, the higher the level of his/ her personal distress.

To prove the hypothesis that higher resilience correlate with higher score of mental health, we also see both of the dimension of mental health. From the result we can interpret that the higher the score of resilience, the better the mental health of the student. We can also see it from the negative aspect of mental health, which is the personal distress. The result shows that the lower the score of resilience, the higher the level of the student personal distress.

Further, we also want to see the relationship between resilience and religiosity. We then want to know which factor of religiosity that correlate with resilience, and found out three factors involved. Those three factors are religious exclusivity $(\mathrm{p}<0.01)$, personal practice $(\mathrm{p}<0.001)$, and religious salience $(\mathrm{p}<0.01)$. We interpreted that the higher the score of resilience, students tend to more exclusive on their religion, more often conduct their personal religion practice, and more internalizing their religious identity. This is also interesting evidence when we found that religiosity and resilience are correlated, but we want to know why these factors were involved, not the other factors.

From our results, we proposed a model for relationship between resilience, the five dimension of religiosity and mental health.

A research shown that high level of religiosity can improve resilience [46]. Religious belief could be a predictor variable for resilience, but it doesn't shown in this research [47]. We suggest perhaps it is because this research were using self-report survey, and for further research there might be some way using a method of training or observation so that the other factors of religiosity could be more manifest.

The religiosity factors that were significantly correlated with other factors is the personal practice. We cannot forget that the data were taken in a public school, not a religious school. We want to know further, whether, we can get the same results if we conduct the survey in a religious school, whether it is Islamic School or Catholic School.

Why we curious about the result, because in public school, the internalization of the religious belief is not conducted at school. The student also not obligated to do external religion practice like Friday prayer for Muslim, or Sunday prayer for Catholic/Christian, not like those student at religious school. We can conclude ourselves that no wonder the score of personal practice is highly correlated when we measure religiosity at public school, because the other factors of religiosity is not obligated to the student of public school not like to those student the religious school.

On the other hand, we can say that if the religious salience of the student at public school is high, it is really because of the student themselves has internalized their religion or because of their environment at home, not because of the school institution that internalize their religious identity. To get to this conclusion, we need to get more diverse population from the student of public school, from other area in Indonesia.

\section{CONCLUSIONS AND RECOMMENDATIONS}

We found that personal practice and religious salience were correlated with mental health well-being. Personal practice also negatively correlated with mental health personal distress. We also found that mental health well-being are very significantly correlated with resilience, yet mental health personal distress are negatively correlated with resilience. These results answer our hypothesis that mental health is correlated with resilience and religiosity. We 
proposed a model for relationship between resilience, the five dimension of religiosity and mental health.

For further research, we suggest a larger number of populations conducted for mental health school survey in public school, religious school including Islamic School and Catholic/Christian school. We also suggest that the data were not only taken on the form of survey, but in a package of training and observation, this method will improve the possibility to get more reliable data of other factors of religiosity, for example, religious belief.

\section{ACKNOWLEDGEMENTS}

We would like to thank you the experts of Mental Health Indonesia Foundation for helping us in the topic of this research, also the school managements that participate in this research. The Education Office Kantor Dinas Pendidikan Wilayah II for giving us permission of the survey. The Psycap Questionnaire is under copyright from mindgarden.com. Many thanks to LPPM -UIN Syarif Hidayatullah Jakarta for making all the things happen. The Psycap Questionnaire were used under the permission from the author and mindgarden.com for Mentally Health School research.

\section{REFERENCES}

[1] Kesehatan, K., Penelitian, B., \& Kesehatan, P. (2018). Hasil Utama RISKESDAS 2018. Jakarta [ID]: Balitbangkes Kementerian Kesehatan.

[2] WHO., 2003. Investing in Mental Health. (T. G. Sàrl, Ed.) Avenue Appia, Geneva, Switzerland: Nove Impression.

[3] Galderisi S., Heinz A., Kastrup M., Beezhold,J.,Sartorius,N. (2015). Toward a new definition of mental health. World Psychiatry, 14(2)

[4] Damayanti R., Aeni, T. (2016). Efektivitas Konseling Behavioral Dengan Teknik Modeling untuk Mengatasi Perilaku Agresif pada Peserta Didik Kelas VIII B SMP Negeri 07 Bandar Lampung. Jurnal Bimbingan Konseling. 3(1)

[5] Risthantri, P., Sudrajat, A. (2015). Hubungan Antara Pola Asuh Orang Tua dan Ketaatan Beribadah Dengan Perilaku Sopan Santun Peserta Didik. Harmoni Sosial: Jurnal Pendidikan 2(2), 191-202.

[6] Rost, K., Smith, J. L., \& Dickinson, M. (2004). The Effect of Improving Primary Care Depression Management on Employee Absenteeism and Productivity. Medical Care, 42(12), 1202-1210.

[7] Anthony, H. and McLean, L.A., 2015. Promoting mental health at school: short-term effectiveness of a popular school-based resiliency programme. Advances in School Mental Health Promotion, 8(4), pp.199-215.

[8] McGrath, H. \& Noble, T. (2003). BOUNCE BACK! A classroom resiliency program. (Teacher's Handbook. Teacher's Resource Books, Level 1: K-2; Level 2: Yrs 3-4; Level 3: Yrs 5-8).Pearson Education: Sydney

[9] Waasdorp, T.E., Berg, J., Debnam, K.J., Stuart, E.A. and Bradshaw, C.P., 2018. Comparing social, emotional, and behavioral health risks among youth attending public versus parochial schools. Journal of school violence, 17(3), pp.381-391.

[10] Jakovljevic, M., 2017. Resilience, Psychiatry and Religion from Public and Global Mental Health Perspective. Psychiatria Danubina, 29, 238.

[11] Mahudin, N. D., Noor, N. M., \& Mariam Adawiah Dzulkifli, N. S., 2016. Religiosity among Muslims: A Scale Development and Validation Study. Makara Hubs-Asia, , 20, 109. 
[12] Huppert, F. A, 2009. Psychological Well-being: Evidence Regarding its Causes and Consequences †. APPLIED PSYCHOLOGY: HEALTH AND WELL-BEING , 2.

[13] Veit, C. T., \& Ware, J. E. (1983). The structure of psychological distress and wellbeing in general populations. Journal of Consulting and Clinical Psychology, 51(5), 730-742.

[14] Boas, A. A., \& Morin, E. M., 2014. psychological well-being and psychological distress for professors in brazil and canada 1 (special ed., Vol. 15(6)). Sao Paulo: UNIVERSIDADE PRESBITERIANA MACKENZIE.

[15] Graber, R., Pichon, F., \& Carabine, E., 2015. Psychological resilience State of knowledge and future research agendas. Blackfriars Road, London : Overseas Development Institute.

[16] Masten, A. S., 2001, March. Resilience Processes in Development. (K. M. King, Ed.)

[17] Kobylarczyk, M., Ogińska-Bulik, Nina. (2017). Assessing resiliency and personal growth in a group of adolescents experiencing negative life events: the mediating role of emotional intelligence. Current Issues in Personality Psychology. 5. 1-10.

[18] Sikorska, I., 2014, January. Theoretical Models Of Resilience And Resilience Measurement Tools In Children And Young People.

[19] Luthans, F., 2002. The need for and meaning of positive organizational behavior. Journal of Organizational Behavior

[20] Selvaraj, P.R. and Bhat, C.S., 2018. Predicting the mental health of college students with psychological capital. Journal of Mental Health, 27(3), pp.279-287.

[21] Holdcroft, B., 2006. What Is Religiosity? A Journal of Inquiry and Practice , 10, 8991.

[22] Cardwell, J. D. (1980). The social context of religiosity. Lanham, MD: University Press of America

[23] Demerath, N. J., III, \& Hammond, P. E. (1969). Religion in social context. New York: Random House.

[24] Glock, C. Y., \& Stark, R. (1965). Religion and society in tension. San Francisco: Rand McNally

[25] Pearce, L. D., Hayward, G. M., \& Pearlman, J. A., 2017, April 4. Measuring Five Dimensions of Religiosity Across Adolescence. Relig Res, 03.

[26] Glock, C. Y. (1972). On the Study of Religious Commitment, in J. E. Faulkner (ed.) Religion's Influence in

Contemporary Society, Readings in the Sociology of Religion, Ohio: Charles E. Merril: 38-56.

[27] Verbit, M. F. (1970). The components and dimensions of religious behavior: Toward a reconceptualization of religiosity. In P. E. Hammond \& B. Johnson (Eds.), American mosaic (pp. 24-39). New York: Random House.

[28] George L, Ellison C, Larson D. Explaining the relationships between religious involvement and health. Psychological Inquiry. 2002;13:190-200.

[29] Harding, Stephen \& Flannelly, Kevin \& Weaver, Andrew \& Costa, Karen. (2005). The Influence of Religion on Death Anxiety and Death Acceptance. Mental Health, Religion \& Culture. 8. 253-261.

[30] Pearce, L. D., \& Denton, M. (2011). A faith of their own: Stability and change in the religiosity of America's adolescents. New York, NY: Oxford University Press.

[31] Lenski, Gerhard. 1961. The Religiou.s Factor. New York: Doubleday

[32] King, M. 1967. "Measuring the Religious Variable: Nine Proposed Dimensions." Journal for the Scientific Stuidy of Religion 6(Fall): 173-90.

[33] Pargament, K. I. (2002). The bitter and the sweet: An evaluation of the costs and benefits of religiousness. Psychological Inquiry, 13(3), 168-181.

[34] Christian, S. Theorizing religious effects among American adolescents. Journal for the Scientific Study of Religion. 2003;42(1):17-30. 
[35] Burdette, A. M., \& Hill, T. (2009). Religious involvement and transitions into adolescent sexual activities. Sociology of Religion: A Quarterly Review, 70(1), 28-48.

[36] Wimberley, D. W. (1989). Religion and Role-Identity: A Structural Symbolic Interactionist Conceptualization of Religiosity. The Sociological Quarterly, 30(1), 125-142.

[37] Stryker, S., \& Serpe, R. T. (1994). Identity salience and psychological centrality: Equivalent, overlapping, or complementary concepts? Social Psychology Quarterly, 57(1), 16-35.

[38] Johnson-Hanks J, Bachrach CA, Kohler H-P, Morgan SP. Understanding Family Change and Variation: Towards a Theory of Conjunctural Action. Springer; New York: 2011.

[39] Stryker Sheldon. Identity Salience and Role Performance: The Relevance of Symbolic Interaction Theory for Family Research. Journal of Marriage and the Family. 1968;30:558-564.

[40] Afzal, A., Atta, M. and Malik, N.I., 2016. Role of Positive Psychological Capital in Prediction of Emotions and Subjective Wellbeing among Adolescents. Journal of the Indian Academy of Applied Psychology, 42(1), p.72.

[41] Kuo, Z., Sai, Z. and Yinghong, D., 2010. Positive Psychological Capital: Measurement and Relationship with Mental Health [J]. Studies of Psychology and Behavior, 1 .

[42] Wong, Y.J., Rew, L., \& Slaikeu, K. D., 2006. A Systematic Review of recent research on adolescent religiosity/spirituality and mental health. Issues in mental health nursing, 27 (2), 161183.

[43] AbdAleati, N.S., Zaharim, N.M. and Mydin, Y.O., 2016. Religiousness and mental health: Systematic review study.

[44] Dankulincova Veselska, Z., Jirasek, I., Veselsky, P., Jiraskova, M., Plevova, I., Tavel, P. and Madarasova Geckova, A., 2018. Spirituality but not Religiosity Is Associated with Better Health and Higher Life Satisfaction among Adolescents. International journal of environmental research and public health, 15(12), p.2781.

[45] Damiano, R.F., de Andrade Ribeiro, L.M., Dos Santos, A.G., Da Silva, B.A. and Lucchetti, G., 2017. Empathy is associated with meaning of life and mental health treatment but not religiosity among Brazilian medical students. Journal of religion and health, 56(3), pp.1003-1017

[46] Kasen, S., Wickramaratne, P., Gameroff, M. J., \& Weissman, M. M. 2012. Religiosity and resilience in persons at high risk for major depression. Psychological medicine, 42(3), 509-519.

[47] Javanmard, G. H. (2013). Religious Beliefs and Resilience in Academic Students. Procedia - Social and Behavioral Sciences, 84, 744-748. 


\section{APPENDIX}

\section{Appendix 1 Principal Component Religiosity Scale}

Principal Component Analysis

\begin{tabular}{|c|c|c|c|c|c|c|}
\hline & RC 1 & $\mathrm{RC} 2$ & RC 3 & RC 4 & RC 5 & Uniqueness \\
\hline GRS1 & . & & & 0.786 & & 0.222 \\
\hline GRS10 & & & & & 0.613 & 0.600 \\
\hline GRS11 & & & 0.698 & & & 0.485 \\
\hline GRS12 & & & & 0.437 & 0.496 & 0.425 \\
\hline GRS13 & & & 0.585 & & & 0.554 \\
\hline GRS14 & & & 0.627 & & & 0.591 \\
\hline GRS15 & 0.777 & & & & & 0.384 \\
\hline GRS16 & & & & 0.831 & & 0.171 \\
\hline GRS17 & & & 0.582 & & & 0.622 \\
\hline GRS18 & 0.441 & & & & & 0.526 \\
\hline GRS19 & & 0.535 & & & & 0.684 \\
\hline GRS2 & & 0.530 & & & 0.443 & 0.585 \\
\hline GRS20 & & 0.485 & & & 0.561 & 0.469 \\
\hline GRS21 & & 0.737 & & & & 0.464 \\
\hline GRS3 & 0.712 & & & & & 0.464 \\
\hline GRS4 & & & & & & 0.780 \\
\hline GRS5 & & 0.548 & & & & 0.485 \\
\hline GRS6 & 0.804 & & & & & 0.268 \\
\hline GRS7 & & & 0.504 & & & 0.705 \\
\hline GRS8 & & & & & -0.482 & 0.703 \\
\hline GRSQ & 0.448 & & & & & 0.521 \\
\hline
\end{tabular}

\section{Appendix 2 Principal Component} Analysis of Psycap Resilience

\section{Principal Component Analysis}

Component Loadings

\begin{tabular}{llc}
\hline & RC 1 & Uniqueness \\
\hline PCQ1R & & 0.960 \\
PCQ2 & 0.548 & 0.700 \\
PCQ3 & 0.696 & 0.515 \\
PCQ4 & 0.666 & 0.557 \\
PCQ5 & 0.743 & 0.448 \\
PCQ6 & 0.649 & 0.579 \\
\hline
\end{tabular}

Note. Applied rotation method is promax.

Chi-squared Test

\begin{tabular}{cccc}
\hline & Value & df & $p$ \\
\hline Model & 22294 & 9 & 0.008 \\
\hline
\end{tabular}

\section{Appendix 3 Principal Component} Analysis of MHI-38 Analysis of General

\section{Principal Component Analysis}

Component Loadings

\begin{tabular}{|c|c|c|c|}
\hline & $\mathrm{RC} 1$ & $\mathrm{RC} 2$ & Uniqueness \\
\hline MHI1 & . & 0.589 & 0.688 \\
\hline MHIIO & . & 0.844 & 0.599 \\
\hline MHI11 & 0.643 & . & 0.639 \\
\hline MHI12 & & & 0.811 \\
\hline MHI13 & 0.578 & & 0.682 \\
\hline MHI14 & & & 0.861 \\
\hline MHI15 & 0.450 & & 0.773 \\
\hline MHI16 & . & -0.400 & 0.670 \\
\hline MHI17 & . & . & 0.656 \\
\hline MHI18 & . & 0.435 & 0.699 \\
\hline MHI19 & 0.777 & . & 0.396 \\
\hline$M H \mid 2$ & & -0.451 & 0.674 \\
\hline $\mathrm{MH} / 2 \mathrm{O}$ & 0.607 & . & 0.680 \\
\hline$M H \mid 21$ & & . & 0.852 \\
\hline MHI22 & & & 0.892 \\
\hline MHI23 & & & 0.928 \\
\hline MHI24 & . & . & 0.736 \\
\hline$M H \mid 25$ & 0.672 & . & 0.585 \\
\hline MHI26 & & 0.483 & 0.801 \\
\hline MHI27 & 0.605 & . & 0.493 \\
\hline MHI28 & . & . & 0.770 \\
\hline MHI29 & 0.673 & . & 0.559 \\
\hline $\mathrm{MH} \mid 3$ & 0.584 & & 0.586 \\
\hline MHIIO & 0.794 & & 0.354 \\
\hline MHI31 & & 0.737 & 0.430 \\
\hline MHI32 & 0.774 & . & 0.454 \\
\hline MHI33 & 0.706 & . & 0.582 \\
\hline MHII34 & . & 0.635 & 0.529 \\
\hline MHII35 & 0.455 & . & 0.813 \\
\hline MHII36 & . & . & 0.747 \\
\hline MHI37 & . & . & 0.915 \\
\hline MHI38 & 0.737 & & 0.426 \\
\hline $\mathrm{MHI} 4$ & . & 0.523 & 0.774 \\
\hline MHI5 & & 0.597 & 0.704 \\
\hline MHI6 & & & 0.786 \\
\hline MHI7 & 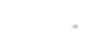 & 0.625 & 0.672 \\
\hline MHII & -0.696 & . & 0.593 \\
\hline MHIO & 0.507 & . & 0.683 \\
\hline
\end{tabular}




\section{Appendix 4 Correlation Matrix of \\ Mental Health, Resilience, and \\ Religiosity}

\section{Correlation Matrix}

Pearson Correlations

\begin{tabular}{|c|c|c|c|c|c|c|c|c|c|c|}
\hline & MHIPD & MHIPWB & MHITOT & PCQTOT & GRSRB & GRSRE & GRSEP & GRSPP & GRSRS & GRSTOT \\
\hline MHIPD & - & & & & & & & & & \\
\hline MHIPWE & $-0.458^{x+x}$ & - & & & & & & & & \\
\hline MHITOT & $-0.932^{200}$ & $0.738^{\mathrm{rex}}$ & - & & & & & & & \\
\hline PCQTOT & $-0.198^{x}$ & $0.368^{x k \star}$ & $0.293^{x t}$ & - & & & & & & \\
\hline GRSRB & -0.186 & 0.149 & 0.144 & 0.168 & - & & & & & \\
\hline GRSRE & -0.002 & 0.067 & 0.014 & $0.254^{* t}$ & $0.290^{* *}$ & - & & & & \\
\hline GRSEP & -0.121 & 0.144 & 0.171 & 0.163 & 0.134 & $0.279 " *$ & - & & & \\
\hline GRSPP & $-0.264^{t+t}$ & $0.210^{*}$ & $0.236^{\circ}$ & $0.324^{+* t+}$ & $0.473^{\text {+*t }}$ & $0.340^{\circ+\infty}$ & $0.218^{*}$ & - & & \\
\hline GRSRS & -0.019 & $0.291 *$ & 0.130 & $0.268 *$ & $0.407^{+\cdots *}$ & $0.234^{\prime}$ & 0.092 & $0.279^{\circ-}$ & - & \\
\hline GRSTOT & $-0.239^{\circ}$ & $0.285^{\circ+}$ & $0.279^{\circ+}$ & $0.349^{* 16}$ & $0.567^{\circ+4}$ & $0.547^{*+t}$ & $0.663^{*+4}$ & $0.800^{\mathrm{str}}$ & $0.469^{*+4}$ & - \\
\hline
\end{tabular}

\section{Appendix 5 Descriptive Statistics of the} Variables

\section{Descriptive Statistics}

Descriptive Statistics

\begin{tabular}{|c|c|c|c|c|c|c|c|c|c|c|c|}
\hline & MHIPD & MHIPWE & MHITOT & PCQTOT & GRSRB & GRSRE & GRSEP & GRSPP & GRSRS & GRSTOT & Jeniskelamin \\
\hline Valid & 110 & 108 & 108 & 115 & 114 & 115 & 111 & 114 & 112 & 108 & 98 \\
\hline Missing & 5 & 7 & $\theta$ & 0 & 1 & 0 & 4 & 1 & 3 & 8 & 17 \\
\hline Mean & 85.845 & 54.102 & 158.236 & 23.600 & 11.788 & 7.288 & 8.819 & 14.482 & 8.383 & 50.845 & \\
\hline Minimum & 36.000 & 37.000 & 109.000 & 11.000 & 8.000 & 5.000 & 5.000 & 5.000 & 4.000 & 32.000 & \\
\hline Maximum & 103.000 & 78.000 & 208.000 & 34.000 & 14.000 & 8.000 & 13.000 & 18.000 & 10.000 & 60.000 & \\
\hline
\end{tabular}

Note Not all values are available for Nominal Text variables 
Appendix 6 Proposed Working Model

Between Resilience, Religiosity, and Mental Health

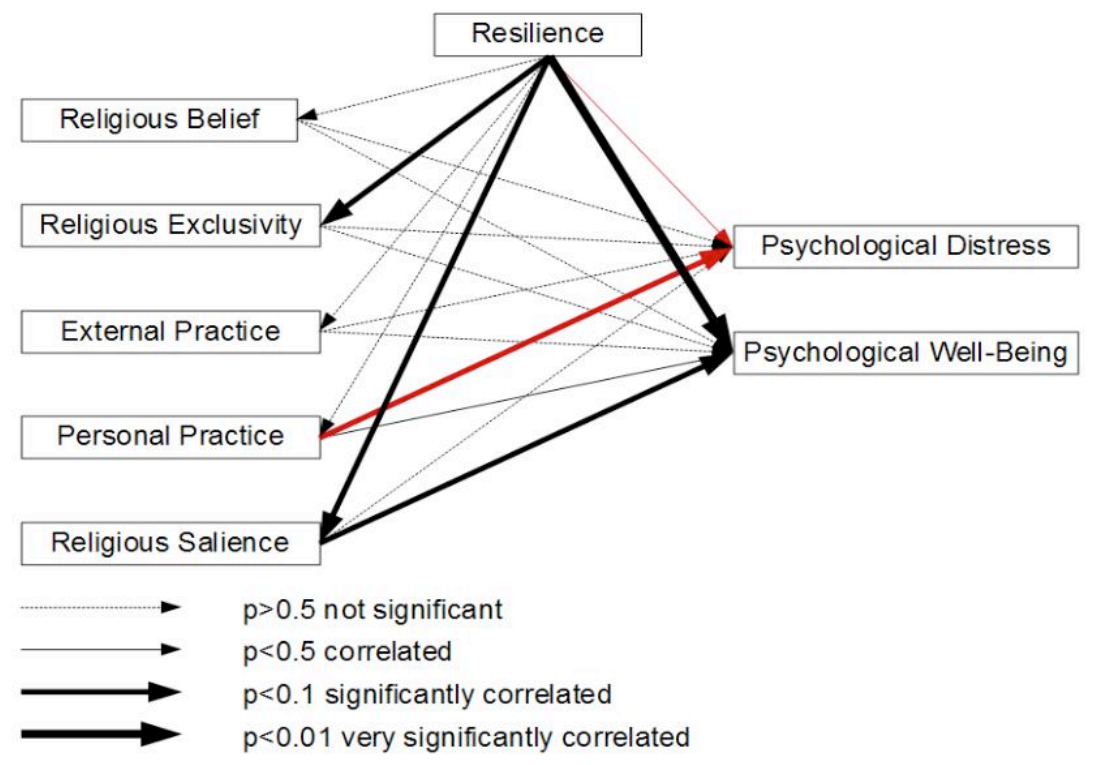


